УДК 656.21

\title{
ПІДВИЩЕННЯ ЯКОСТІ ОРГАНІЗАЦІЇ ТРАНЗИТНИХ ПЕРЕВЕЗЕНЬ ЗАЛІЗНИЦЯМИ УКРАЇНИ В СУЧАСНИХ УМОВАХ
}

Магістрант Д.І. Реутов

ПОВЫШЕНИЕ КАЧЕСТВА ОРГАНИЗАЦИИ ТРАНЗИТНЫХ ПЕРЕВОЗОК
ЖЕЛЕЗНЫМИ ДОРОГАМИ УКРАИНЫ ВСОВРЕМЕННЫХ УСЛОВИЯХ

Магистрант Д.И. Реутов

\section{THE QUALITY IMPROVEMENT ORGANIZATION TRANSIT RAILWAYS OF UKRAINE IN CURRENT CONDITIONS}

\author{
master student D.I. Reutov
}

Сприятливе географічне положення України, наявність розвинутої транспортної інфраструктури, а також показники експорту-імпорту країн сусідів дають змогу зробити висновок про спільну защікавленість у підвищенні якості організащії транзитних перевезень.

Ключові слова: транзитні перевезення, транспортна інфраструктура, міжнародні транспортні коридори, транзитні вантажопотоки.

Благоприятное географическое положение Украины, наличие развитой транспортной инфраструктуры, а также показатели экспорта-импорта стран соседей позволяют сделать вывод об общей заинтересованности в повышении качества организации транзитных перевозок.

Ключевые слова: транзитные перевозки, транспортная инфраструктура, международные транспортные коридоры, транзитные грузопотоки.

The favorable geographical position of Ukraine, a well-developed transport infrastructure, as well as indicators of export-import of neighbours suggest a General interest in improving the quality of the organization of transit.

Keywords: transit, transport infrastructure, international transport corridors, transit traffic.

Вступ і постановка проблеми у загальному вигляді та їі зв'язок із важливими науковими та практичними завданнями. Україна $є$ активним учасником глобальної та регіональної економічної діяльності. Вона має винятково вигідне географічне положення - якраз на шляху значних транзитних товаропотоків між Азією та Європою, Північчю та Півднем. Наявність розгалуженої транспортної мережі за умов активної зовнішньоекономічної діяльності, перетворює нашу державу у провідного транзитера на всьому євразійському просторі. Потенціал збільшення транспортних потоків та заходи щодо формування Єдиного Економічного Простору стимулюють Україну до реалізації свого потужного транзитного потенціалу. I це $є$ тим логічніше, що саме Україні за даними проведених досліджень [1] присвоєно коефіцієнт 3,11 - найвищий транзитний рейтинг серед усіх європейських країн.

Залізниці України $є$ не тільки вагомою частиною народно господарського комплексу країни,але також служать значним транзитним коридором між Сходом i Заходом. Сьогодні вони безпосередньо межують і взаємодіють із залізницями Росії, Білорусі, Молдови, Польщі,Румунії, Словаччини, Угорщини, забезпечують роботу 3 міжнародним 56 залізничним переходах, а також обслуговують 18 українських морських портів ЧорноморськоАзовського басейну, а також річок Дніпра та Дунаю.

Визначення мети та задачі дослідження. Позначити методи підвищення 
якості в організації транзитних перевезень по залізницям України, та підвищення ефективності перевезень, в сучасних.

Аналіз останніх

Питанням дослідження транспортних коридорів та транзитних перевезень в Україні присвячені значна кількість праць $[8,9,10,11]$, але в сучасних умовах інформаційних та автоматизованих систем виникає необхідність перегляду деяких підходів.

Основна частина дослідження. Глобалізація економіки і супроводжуючі ii процеси розвитку зовнішньоторговельного обміну вимагають нових підходів до розвитку транспорту, пошуку нових технологій і раціональних шляхів освоєння перевезень пасажирів i вантажів. Розширення міжнародного співробітництва та поглиблення інтеграційних процесів викликали необхідність створення міжнародної транспортної інфраструктури.

Для підвищення ефективності зовнішньо торговельних і транзитних зв'язків міжнародні організації зацікавлені європейські та азіатські країни приступили до формування системи міжнародних транспортних коридорів (МТК). В умовах розширення міжнародного співробітництва та поглиблення інтеграційних процесів, формування МТК належить провідна роль у вирішенні транспортних проблем,пов'язаних i3 забезпеченням міждержавних економічних, культурних та інших зв'язків, 3 доцільністю

створення

міжнародної

транспортної інфраструктури.

Проаналізуємо основні показники зовнішньоекономічних перевезень залізниць України, для можливості розробки ефективних та дієвих пропозицій щодо збільшення обсягів та підвищення якості транзитних перевезень на залізницях України.

Економіка України значною мірою орієнтована на зовнішню торгівлю. Це значить, що транспортно-економічні зв'язки за часів незалежності перетерпіли докорінні зміни. Їх основна частина перейшла в категорію міжнародних: експортних, імпортних i транзитних. Причому транзит перевищує експорт та імпорт більш ніж у два рази.

За рахунок експорту в Україні формується понад 50\% ВВП, тоді як 50\% ВВП припадає на імпорт. Таким чином, економіка України більш ніж на 100\% пов'язана із зовнішньоторговельним оборотом.

Основний

обсяг

зовнішньоекономічних вантажопотоків проходить у напрямку Схід-Захід. 3 країнами СНД Україна формує близько 50\% експортно-імпортних товаропотоків, на них припадає 90\% транзиту

У таблиці 1.1 наведено дані про динаміку транзитних вантажів кожним видом транспорту за 7 років.

Таблиця 1.1

Динаміка транзитних вантажопотоків за видами транспорту, тис. т

\begin{tabular}{|l|l|l|l|l|l|l|l|}
\hline & 2005 & 2006 & 2007 & 2008 & 2009 & 2010 & 2011 \\
\hline Усього & 205565,25 & 222948,1 & 386956,6 & 325423 & 178134,1 & 152353,8 & 151243,0 \\
\hline трубопровідним & 127921,9 & 143721,2 & 279802,4 & 223497,9 & 127981,7 & 99440,26 & 93119,52 \\
\hline залізничним & 73221,04 & 75050,72 & 99882,37 & 93347,6 & 44834,64 & 44511,77 & 48669,54 \\
\hline морським & 3765,54 & 2516,11 & 2693,97 & 3486,97 & 1899,38 & 3660,41 & 3912,07 \\
\hline автомобільним & 636,1 & 1614,14 & 4494,61 & 4908,71 & 3354,2 & 4649,12 & 5011,2 \\
\hline річковим & 10,11 & 18,5 & 37,43 & 74,73 & 0 & 0 & 0 \\
\hline авіаційним & 1,4 & 1,17 & 1,28 & 1,54 & 1,17 & 1,58 & 2,8 \\
\hline інше & 9,16 & 26,33 & 44,54 & 105,54 & 62,94 & 90,64 & 527,84 \\
\hline
\end{tabular}

3 таблиці 1.2, яка наочно зображує динаміку зміни вантажопотоки, зокрема залізничного транспорту України у транзитному сполученні протягом періоду з
2005 по 2011 роки, можна зробити висновок, що протягом останніх років спостерігалося поступовий спад обсягів міжнародного транзиту, виконаного залізничниками 
України з 2008 року пов'язується перш за все 3 економічною кризою, яка охопила світове виробництво товарів.

Транзитним потенціалом країни називають інтегральний показник потенціальних транзитних можливостей території країни з урахуванням пропускної спроможності іiї транспортно-транзитної інфраструктури. Він має декілька видів: наявний, перспективний та реально затребуваний. Останній кількісно характеризує конкурентоспроможність даної країни на світовому транспортному ринку [2]. Транзитний потенціал країни не є сталою величиною. Він змінюється залежно від динаміки кількісних та якісних характеристик потужностей об'єктів і засобів транзиту, а також від створених умов i встановлених правил функціонування сфери транспорту.

Визначальним фактором, що має безпосередній вплив на частку транзитного потенціалу України, яка реалізується залізничним транспортом, є технічний стан вітчизняної залізничної мережі. Починаючи з 1990 року залізниці України, незважаючи на економічні труднощі в державі, постійно модернізувалися та розвивалися.

Експлуатаційну характеристику залізничних шляхів сполучення наведено у таблиці 1.2 на основі [3].

Таблиця 1.2

Експлуатаційна характеристика залізниць України в динаміці протягом 1990-2010 років

\begin{tabular}{|l|c|c|c|}
\hline \multicolumn{1}{|c|}{ Показники } & \multicolumn{3}{|c|}{ Період } \\
\cline { 2 - 4 } & $\mathbf{1 9 9 0}$ & $\mathbf{2 0 0 0}$ & $\mathbf{2 0 1 0}$ \\
\hline $\begin{array}{l}\text { 1. Колії загального користування, в тому числі } \\
\text { електрифіковані, тис. км. }\end{array}$ & 8,1 & 9,1 & 9,1 \\
\hline Частка від загальної довжини, \% & 36 & 41 & 41 \\
\hline 2. Неелектрифіковані, тис. км & 14,7 & 13,2 & 12,1 \\
\hline Частка від загальної довжини, \% & 64 & 59 & 56 \\
\hline 3. Двоколійні, багатоколійні дільниці, тис. км & 7,6 & 7,3 & 7,2 \\
\hline Частка від загальної довжини, \% & 33 & 33 & 33 \\
\hline 4. Обладнані автоблокуванням, тис. км & 14,1 & 13,5 & 13,4 \\
\hline Частка від загальної довжини, \% & 62 & 60 & 59 \\
\hline
\end{tabular}

Значну роль при залученні транзитних вантажів відіграють експедиторські компанії: на їх долю припадає більше половини транзитного вантажопотоку, а на прикладі країн 3 розвиненою ринковою економікою видно, що саме експедиторська діяльність становить від 4 до $10 \%$ валового внутрішнього продукту.

На розвиток та реалізацію експортного потенціалу українського транспортного комплексу впливає велика кількість різноманітних факторів. Ступінь їх впливу неоднакова, проте, як показує практика виключити будь-який 3 них не можна.

3 метою підвищення ефективності зовнішньоторговельних і транзитних зв'язків міжнародні організації зацікавлені європейські та азіатські країни сформували систему міжнародних транспортних коридорів (МТК), і цей процес триває. В даний час МТК відіграють провідну роль у вирішенні транспортних проблем, пов'язаних iз забезпеченням міждержавних економічних, культурних та інших зв'язків.

У Європі 3 проектом створення транспортних коридорів виступила Єврокомісія ще в 1980-х роках. Його основною метою стала оптимізація транспортних потоків в Західній Європі. При цьому акцент був зроблений на розвиток транспортної інфраструктури країн Східної Європи для забезпечення зростання вантажопотоку між Європою і країнами Південно-Східної Азії. Використання для цих цілей портів Болгарії, Румунії та України дозволяє розвантажити від автотранспорту дороги Західної Європи. Ця політика відповідає і загальній стратегії $€$, спрямованої на підвищення екологічних стандартів і збільшення частки найбільш 
екологічних видів транспорту: залізничного і водного. У країнах ЄС 44\% від загального обсягу перевезень припадає на автомобільний транспорт, $41 \%$ - на морський, 8\% - на залізничний і 4\% - на внутрішній водний. В Україні в останні роки частка залізничного транспорту становить $50-55 \%$, морського - близько $25 \%$, автомобільного - 20-25\%.

Основні транспортні зв'язки між Україною та іншими державами здійснюються саме за напрямами міжнародних транспортних коридорів, тому ïx розвиток $\epsilon$ пріоритетним напрямком діяльності залізниць України, як основи інтеграції українського залізничного транспорту в європейську i світову транспортні системи.

По території України проходять 3-й, 5-й, 7-й і 9-й пан'європейських коридору:

№ 3 - Брюссель - Аахен - Кельн Дрезден - Вроцлав - Катовіце - Краків - Львів - Київ;

№ 5 - Венеція - Трієст/Копер Любляна - Марібор - Будапешт - Ужгород Львів - Київ, довжина 1 тис. км;

№ 7 - по Дунаю (водний), Австрія Угорщина - Югославія - Болгарія - Румунія Молдова - Україна, довжина 2,3 тис. км;

№ 9 - Гельсінкі - Виборг - СанктПетербург - Псков - Москва - Калінінград Київ - Любашівка/Роздольна (Україна) (з подальшою гілкою до Одеси) - Кишинів Бухарест - Димитровград - Александрополіс (3,4 тис. км).

Крім того, через Україну проходять шість коридорів Організації співробітництва залізниць (ОСЗ):

№3 - Польща - Україна - Росія, загальна протяжність 2209 км;

№4 - Чехія - Словаччина - Польща Угорщина - Україна, загальна протяжність 3 відгалуженнями 2711 км;

№5 - Угорщина - Словаччина Україна - Росія - Казахстан - Грузія Азербайджан - Молдова - Китай Киргизстан, довжина основної траси становить 11486 км; 1520 км;
№8 - Україна - Росія - Казахстан Узбекистан - Туркменістан, загальна протяжність 5115 км;

№10 - Грузія - Азербайджан Туркменістан - Узбекистан - Киргизстан Таджикистан - Казахстан (наземна частина), 3 використанням поромних переправ 3 Болгарії, Румунії і України в Грузинський морські порти, загальна протяжність коридору - 8847 км [4].

У 1996 р. Україна приєдналася до МTК Свропа - Кавказ - Азія (TRACECA), спільно 3 Польщею почалася реалізація проектів МТК Гданськ - Одеса, а також Європа - Азія (через прикордонні переходи у Донецькій i Луганській областях 3 направленням на Казахстан).

У перспективі передбачається створення нового транспортного коридору Азія-Свропа через Україну, Росію, Словаччину та Австрію 3 шириною колії 1520 мм. Для цього необхідно буде побудувати близько 500 км ж/д колії від словацького Кошице до Відня.

Загальна протяжність мережі залізничних транспортних коридорів на території України становить 3,2 тис. км і сьогодні за обсягами таких вантажних перевезень українські залізниці посідають четверте місце в Європі та шосте у світі (понад 60\% усіх транзитних вантажів).

В останні роки, поряд з ослабленням транзитного потенціалу України, продовжується розробка і реалізація великих міжнародних транспортних проектів, передбачають створення євроазіатських зв'язків в обхід території України на основі утворення нових коридорів, альтернативних українським. Крім того, значну конкуренцію у сфері залізничного транзиту Україна відчуває 3 боку сусідніх держав, зокрема, Республіки Білорусь.

Для залучення вантажів залізничні адміністрації України, Грузії, Казахстану та Азербайджану погодили наскрізні тарифи i ввели знижки на друге півріччя 2010 р. на перевезення універсальних контейнерів міжнародним транспортним коридором. Зокрема, «Укрзалізниця» ввела $20 \%$ знижку на перевезення великотоннажних 
універсальних контейнерів 3 країн $Є C$ в порти Іллічівськ, Керч, Одеса і у зворотному напрямку [7].

Значну увагу на залізних дорогах України приділяється розвитку інтермодальних перевезень, забезпечують можливість одночасного перевезення у складі поїзда універсальних і спеціалізованих контейнерів, а також автопоїздів.

Міжнародні транспортні коридори на території України мають велике державне значення. Ихдальнейшее розвиток являє собою досить складну проблему, що включає комплекс різних технічних, організаційних, економічних, юридичних та інших питань. Однією 3 головних цих проблем $\epsilon$ неузгодженість дій окремих елементів єдиної транспортної ланцюга, відсутність ефективної координації в роботі профільних органів державного управління та силових структур, недосконалі прикордонні та митні процедури, а також корупція на всіх рівнях організації транспортування вантажів. Непрозорість митних i прикордонних процедур при перетині кордону створюють значні бар'єри для торгівлі, що не дає можливості Україні повністю реалізувати свій потенціал транзитної країни. Та власники вантажів, та представники їх інтересів, у процесі перевезення експедитори, вказують на те, що в Україні доводиться оформляти велику кількість документів, передбачених регламентом роботи як «Укрзалізниці», так і контролюючих органів (митниці, санітарного та ветеринарного контролю, прикордонників та багатьох інших). Тому, якщо не будуть спрощені процедури контрольно- перевірочних операцій оформлення документів на транзитні вантажі, гармонізоване законодавство транспортників i митниці, вдосконалено правова база в частині забезпечення збереження вантажів при транспортуванні, впроваджено сучасні інформаційні системи, що спрощують документообіг, - поліпшити ситуацію 3 транзитними перевезеннями навряд чи вдасться [5].

$\begin{array}{lllr}\text { Висновки } & \text { дослідження } & \text { i } \\ \text { перспективи, подальший } & \text { розвиток } & \text { у } \\ \text { даному напрямку. Таким } & \text { чином, для }\end{array}$ даному напрямку. Таким чином, для до транс'європейської залізничної мережі необхідно: розробити заходи державної підтримки, спрямованої на регулювання міжнародної діяльності; гармонізувати нормативно-правову базу у сфері залізничного транспорту відповідно до міжнародно - правових норм; забезпечити техніко-технологічне зближення рухомого складу та транспортної мережі України 3 європейською транспортною системою; наблизити технічні, технологічні та екологічні стандарти 3 європейськими; привести у відповідність 3 європейськими стандартами шляхом модернізації та реконструкції основні маршрути, які можуть бути включені в загальноєвропейську транспортну систему; розвинути систему інформаційного забезпечення залізничної галузі на основі сучасних інформаційних технологій. Для вирішення всіх цих проблем потрібна координація дій всіх структур, що забезпечують формування та ефективне використання транспортних коридорів. I тут також необхідно посилення регулюючої ролі держави.

\section{Список використаних джерел}

1 Блудова Т. Глобалізація транспортної системи та поняття „транзитний потенціал країни” // Економіка України. - 2006. - № 10. - С. 21-26.

2 Леонтьев Р.Г., Хмель В.А. Альтернативные стратегии развития транзитного потенциала Российской Федерации. // Транспорт: наука, техника, управление. - 2006. - №10. - c. $8-10$.

3 Довідник основних показників роботи залізниць України $(1997$ - 2007 р.) - К.: Укрзалізниця, 2003. - 39с.

4 Глонти А. Международные транспортные коридоры Организации сотрудничества железных дорог / А. Глонти // Бюллетень ОСЖД. - 2009. - № 4-5. - С. 32- 34. 
5 Украина - лидер по мощности транзитного потенциала и аутсайдер по эффективности его использования [Электроний ресурс]. - Режим доступу: http://uzinfo.net/ru/press/13897.

6 Проблемы и перспективы международных транзитных перевозок [Электроний pecypc]. - Режим доступу: http://econindustry.org/arhiv/html/2011/st_56_04.pdf

7 Експортний та траний потенціал України [Электроний ресурс]. - Режим доступу: http://mail.geekrunner.org/83/111/

8 Панченко, С.В. Інтермодальні перевезення як ключовий чинник підвищення ефективності роботи транспорту в умовах формування міжнародних транспортних коридорів України [Текст] / С.В. Панченко // Вісник економіки транспорту і промисловості № 42, 2013С. 7-8

9 Підлісний, П.І. Передумови організації мультимодальних перевезень вантажів вітчизняними операторами на міжнародному ринку транспортних послуг [Текст] / Підлісний П.І., Брайковська А.М // Економіст, № 10 (300), 2011 р. С.25-30.

10 Трансальпийские перевозки компании Railion - состояние, опыт, перспективы / ЖД мира,- №12, - 2006 [Электронный ресурс] // Режим доступа: www/URL:http://www.zdmira.com/ 31. Украина остается одной из рисковых стран региона для интермодальных операторов, Транспорт і логістика, 10.11.2011

11 Козак В.В. Розробка моделі розвитку інтероперабельності міжнародних залізничних транспортних коридорів на стратегічному рівні планування перевезень / В.В. Козак, Т.В. Бутько, А.В. Прохорченко // Інформаційно-керуючі системи на залізничному транспорті. - 2011.- № 3. - С. 36-41.

Рецензент д-р техн. наук, професор О.М.Огар

Реутов Дмитро Ігорович слухач групи МЗ-ОПУТ-13

Dmytro Igorovych Reutov, student of the group M3-ROM-13 